\title{
РОЗСЛІДУВАННЯ НАЙТЯЖЧИХ ЗЛОЧИНІВ, УЧИНЕНИХ В УМОВАХ ЗБРОЙНОГО КОНФЛІКТУ В УКРАЇНІ ЯК ВАЖЛИВИЙ ЕЛЕМЕНТ ПЕРЕХІДНОГО ПРАВОСУДДЯ
}

Конопельський В. Я., Свиридова Д. О.

\begin{abstract}
Метою статті є огляд питання подолання безкарності за найтяжчі злочини, вчинені в умовах збройного конфлікту в Україні як одного з важливих елементів перехідного правосуддя. Відповідно до сталих підходів, визначених у рамках структур Організації Об'єднаних Націй, перехідне правосуддя визначають як комплекс процесів та механізмів, пов'язаних зі спробами суспільства подолати тяжку спадщину великомасштабних порушень законності в минулому з метою забезпечити підзвітність, справедливість і примирення. При цьому перехідне правосуддя включає в себе такі важливі для запровадження у комплексі елементи, як заходи з установлення істини, судове переслідування й запобігання безкарності, відшкодування шкоди та інституційні реформи задля неповторення конфлікту. Фокусом уваги авторів $\epsilon$ питання стану розбудови в Україні ефективного документування та розслідування найтяжчих злочинів, учинених в умовах збройного конфлікту з Російською Федерацією. Автори наголошують на тому, що серед здобутків влади України з документування та притягнення до відповідальності винних у найтяжчих злочинах в умовах збройного конфлікту варто відзначити наміри та заходи з розбудови національної системи розслідування таких злочинів (наприклад, створення Департаменту нагляду у кримінальних провадженнях щодо злочинів, учинених в умовах збройного конфлікту, у структурі Офісу Генерального прокурора). Проте у статті звертається увага на те, що для ефективної розбудови національної системи розслідувань та забезпечення безкарності Україні вкрай необхідно виконати низку домашніх завдань, серед яких - гармонізація національного законодавства та правозастосовної практики у сфері кримінальної юстиції до норм міжнародного кримінального та міжнародного гуманітарного права; законодавче врегулювання питань щодо спечіального кримінального провадження (in absentia) по такій категорії справ; визначення з підходами та законодавче закріплення національного механізму роз-
\end{abstract}

(с Конопельський В. Я., Свиридова Д. О., 2020 слідування та судового розгляду злочинів проти людяності, воєнних злочинів тощо.

Ключові слова: перехідне правосуддя, тимчасово окуповані території, воєнні злочини, злочини проти людяності, грубі порушення прав людини.

Konopelskyi V. Ya., Svyrydova D. O. Investigation of the most serious crimes committed during the armed conflict in Ukraine as an important element of transitional justice

The article explores the fight against impunity for the most serious crimes committed in the context of the armed conflict in Ukraine, which is an important component of transitional justice aimed at dealing with the conflict's effects. In accordance with approaches developed within the framework of the United Nations, transitional justice is defined as a set of processes and mechanisms meant to help society process a bitter legacy of past large-scale wrongdoings in order to ensure accountability, justice and reconciliation. Transitional justice includes such much-needed elements as truthseeking measures, prosecution and prevention of impunity, reparations and institutional reforms aimed at preventing new conflicts in the future. The authors focus on the state of documentation and investigation in Ukraine of the most serious crimes that took place in the context of the armed conflict with Russia. In terms of positive developments for the Ukrainian government in the field of documenting the most serious crimes committed in the context of the armed conflict and prosecuting those responsible, the authors name plans and measures aimed at building a national system for investigating the most serious crimes (for example, establishing a Department for Supervision in Criminal Proceedings involving Offenses Committed in the Context of the Armed Conflict within the structure of the Office of the Prosecutor General). The authors caution, however, that Ukraine needs to do its homework before it can create an effective national system for investigating these crimes and preventing impunity, such as bringing national legislation and practical application of criminal laws in line with international criminal and international humanitarian law; providing legislative regulation for issues related to special criminal proceedings («in absentia») for this category of offenses; defining at legislative level and providing approaches to 
the national mechanism for investigating and prosecuting crimes against humanity, war crimes, etc.

Key words: transitional justice, temporarily occupied territories, war crimes, crimes against humanity, gross human rights violations.

Постановка проблеми та їі актуальність. Збройні конфлікти, що відбуваються в країнах та між країнами, невідворотно змінюють суспільства, спричиняючи наслідки, подолання яких потребує не одного десятиріччя навіть після того, як сама війна завершена. Збройний конфлікт із Російською Федерацією на території України, що розпочався з окупації територій Автономної Республіки Крим та м. Севастополь в лютому 2014 р. та продовжився на частинах територій Донецької та Луганської областей, триває вже сім років.

Тимчасова окупація Російською Федерацією (далі - РФ) території України стала викликом не лише для національної безпеки української держави, а й для спроможності забезпечення ефективного захисту та відновлення прав людини та основоположних свобод в умовах подолання наслідків збройного конфлікту. Так, збройна агресія Російської Федерації проти України призвела до загибелі та поранень значної кількості цивільних жертв, більше мільйона наших громадян із тимчасово окупованих територій були вимушені залишити свої домівки, що призвело до потоків внутрішньо переміщених осіб усередині країни.

Протягом усього часу окупації на цих територіях із боку влади Російської Федерації та підконтрольних їй окупаційних адміністрацій масово та системно вчиняються грубі порушення прав людини, воєнні злочині та злочини проти людяності.

Той факт, що між Україною та Російською Федерацією відбувається міжнародний збройний конфлікт (щонайменше в частині тимчасової окупації території АР Крим та м. Севастополь) визначений у національному законодавстві відповідно до Закону України № 1207-VII від 15.04.2014 та Закону України № 2268-VIII від 18.01.2018. А також, що важливо, відповідно до звітів Офісу Прокурора Міжнародного кримінального суду, в яких з 2016 р. ситуація в Криму визначається як «рівнозначна міжнародному збройному конфлікту між Україною та Російською Федерацією» [3], який розпочався не пізніше 26 лютого 2014 р.

Метою статті $\epsilon$ розгляд питання запровадження системного й ефективного документування та розслідування найтяжчих злочинів, учинених в умовах збройного конфлікту в Україні, як один із заходів задля подолання його наслідків та важливий елемент перехідного правосуддя.
Виклад основного матеріалу. Сукупність процедур та процесів, що застосовуються у світі для переходу країни від стану війни до миру, визначають підходи або засади правосуддя перехідного періоду чи перехідного правосуддя (англ. transitional justice).

Ще у 2004 р. у своїй доповіді на Раді Безпеки Організації Об'єднаних Націй (далі - ООН), присвяченій пануванню права і правосуддя перехідного періоду в конфліктних і постконфліктних суспільствах, Генеральний секретар ООН визначив, що «поняття «правосуддя перехідного періоду» охоплює весь комплекс процесів і механізмів, пов'язаних зі спробами суспільства подолати тяжку спадщину великомасштабних порушень законності в минулому з метою забезпечити підзвітність, справедливість і примирення» [3, пункт 8].

Правосуддя перехідного періоду пов'язано як із судовими, так і з несудовими процесами і механізмами, такими як:

- встановлення істини;

- судове переслідування й запобігання безкарності;

- відшкодування шкоди;

- інституційні реформи.

При цьому вкрай важливим $є$ запровадження всіх чотирьох визначених елементів у комплексі задля досягнення справедливості та розбудови гармонійного шляху від стану війни до стану миру. Перехідне правосуддя має бути спрямоване на комплексне подолання причин конфлікту та пов'язаних із ними порушень громадянських, політичних, економічних, культурних та інших прав.

Від початку збройного конфлікту в Україні тема перехідного правосуддя здебільшого була фокусом уваги та фахових обговорень наукового й експертного середовища в неурядовому секторі.

Проте з 2019 р. питання роботи щодо запровадження засад перехідного правосуддя були включені до завдань відповідних державних органів влади. Так, відповідно до Указу Президента України № 758/2019 від 17.10.2019, Представництву Президента України в Автономній Республіці Крим було доручено вживати заходів для подальшої активізації роботи, зокрема з напрацювання пропозицій щодо концепції перехідного правосуддя. А також питання впровадження засад перехідного правосуддя, підвищення національного потенціалу для врегулювання збройних конфліктів, визначення основ для підтримання миру були винесені й на рівень Кабінету Міністрів України (відповідно до п. 11 положення про Міністерство з питань реінтеграції тимчасово окупованих 
територій України, затвердженого постановою КМУ від 08.06.2016 № 376 у редакції Постанови КМУ від 06.08.2020 № 371).

Окрім того, Указом Президента Україні № 584/2019 від 07.08.2019 створено Комісію з питань правової реформи, у рамках якої працює робоча група з питань реінтеграції тимчасово окупованих територій. Одним із завдань, поставлених членам указаної робочої групи, було напрацювання документів, що б стали відповіддю України на виклики окупації та збройного конфлікту, мінімізували негативні наслідки війни. Нині робоча група завершила роботу та направила Президенту України пропозиції у сфері розбудови заходів із захисту та відновлення прав людини й основоположних свобод в умовах подолання наслідків збройного конфлікту на території України, спричиненого збройною агресією Російської Федерації (концепцію національної моделі перехідного правосуддя).

Загалом практика перехідного правосуддя налічує десятки національних варіантів та концепцій. Кожна країна, що пережила збройний конфлікт, розробляє свою модель перехідного правосуддя, ураховуючи політичну ситуацію, особливості правової практики, національний менталітет. У Резолюції 12/11 Рада з прав людини ООН підкреслює, що «під час розроблення стратегії правосуддя перехідного періоду повинні враховуватися конкретні обставини кожної ситуації, щоб попередити повторення криз і порушення прав людини в майбутньому і забезпечити соціальну згуртованість, державне будівництво...». Проте, аналізуючи чисельні документи та рішення у структурі органів ООН, можна дійти висновку про те, що будь-які національні підходи мають ураховувати наявність таких обов'язкових заходів, як боротьба з безкарністю, розвиток національного потенціалу переслідування винних у скоєнні грубих порушень прав людини та серйозних порушень міжнародного гуманітарного права, виконання зобов'язань щодо справедливих судових розглядів.

Важливо розуміти, що відсутність визначеної та ухваленої державою національної моделі перехідного правосуддя не знімає відповідальності із запровадження заходів щодо подолання наслідків збройного конфлікту, зокрема й розбудови заходів із запобігання безкарності та притягнення до відповідальності винних у найтяжчих злочинах, учинених у ході збройного конфлікту з Російською Федерацією.

Проте чи достатньо зроблено країною задля повного документування, розслідування та при- тягнення до відповідальності винних у найтяжчих злочинах в умовах збройного конфлікту в Україні?

Очевидним здобутком $\epsilon$ те, що така робота ведеться одразу у двох напрямах: міжнародному та національному.

Чисельні факти грубих порушень прав та свобод людини за ці роки не лише ставали предметом вивчення та фокусом уваги в рамках щорічних резолюцій ПАРЄ (наприклад, Резолюція ПАРЄ 2067 (2015) від 25 червня 2015 р. та ін.) або Генеральної Асамблеї ООН «Про стан у сфері прав людини в Автономній Республіці Крим та місті Севастополі (Україна)» (наприклад, Резолюція ООН 71/205 від 19 грудня 2016 р. та ін.), але й тепер будуть розглянуті в рамках міждержавного спору в Європейському суді з прав людини відповідно до рішення від 16 грудня 2020 року, проголошеного 14 січня 2021 р. по справі Ukraine v. Russia (re Crimea).

Окрім того, цілий перелік імовірних воєнних злочинів та злочинів проти людяності, скоріше за все, стане предметом розслідування Офісу Прокурора Міжнародного кримінального суду (далі - МКС). Відповідно до звіту за 2020 р. та заяви прокурора МКС Фату Бенсуда від 11 грудня 2020 р. щодо завершення попереднього розслідування по Україні, «...існують розумні підстави вважати, що широкий діапазон діянь, скоєних у контексті ситуачії в Україні, становлять воєнні злочини та злочини проти людяності в межах юрисдикції Міжнародного кримінального суду ... наступним кроком буде запит на отримання дозволу у суддів досудової палати Суду на відкриття розслідування» [4].

Однак важливо розуміти, що у фокусі уваги розслідування Офісу Прокурора МКС опиняться лише злочини, вчиненні так званими «топ-злочинцями», високопосадовцями влади РФ чи підконтрольних їй збройних формувань та окупаційних адміністрацій. При цьому документування та розслідування більшості злочинів, учинених на окупованих територіях та в ході збройного конфлікту, залишається домашнім завданням для національної правоохоронної та судової систем України.

Окрім того, як зазначають окремі міжнародні експерти, на заваді розслідування Офісу Прокурора МКС може стати й гостра нестача ресурсів цього суду. Офіс Прокурора відчуває значну фінансову скруту через постійний зріст ситуацій на етапах попереднього вивчення та розслідування, при цьому збільшення навантаження ніяк не корелює зі збільшенням бюджету, а до викликів слід додати також проблеми, спричинені 
пандемією COVID-19 [2]. Відповідно, заручитися підтримкою Асамблеї держав-учасниць для вирішення питання щодо надання пріоритету розслідування ситуації по Україні може бути доволі складно. Україна при цьому досі не ратифікувала Римський статут i, відповідно, не має ні права голосу як держава-учасниця, ні сплачує фінансових членських внесків до бюджету цього Суду.

Тож не менш важливим $€$ фокус уваги та напрям зусиль держави саме на розбудову національної системи та механізмів запобігання безкарності за найтяжчі злочини, вчинені в рамках збройного конфлікту з РФ на наших територіях. Упровадження цього елементу перехідного правосуддя потребує від держави не лише змін до законодавства, а й вирішення чисельних питань, що іноді потребують і широкого суспільного діалогу. Серед ключових завдань у цьому напрямі, що стоять перед державою та національною правовою системою, варто відзначити декілька.

Гармонізація національного законодавства та правозастосовної практики у сфері кримінальної юстиції до норм міжнародного кримінального та міжнародного гуманітарного права. Один із розроблених для вирішення цього завдання групою науковців, експертів та народних депутатів законопроєкт «Про внесення змін до деяких законодавчих актів України щодо імплементації норм міжнародного кримінального та гуманітарного права» № 2689 від 27.12.2019 очікує свого розгляду у другому читанні. А питання ратифікації Римського статуту залишається не вирішеним парламентарями, хоча, відповідно до окремих досліджень, більшість населення України підтримує іï членство в Міжнародному кримінальному суді [8, див. результати відповідей на питання 4 дослідження]. Водночас аналіз ситуації та практики досудових проваджень щодо злочинів у рамках збройного конфлікту на сьомому році війни свідчить про суттєві проблеми в першу чергу з належною кваліфікацією такої категорії злочинів. Так, наприклад, за даними органів прокуратури, у шести областях України у період 2014-2018 рр. було зареєстровано 11733 правопорушення, пов'язаних зі збройним конфліктом, з яких по злочинах проти миру, безпеки людства та міжнародного правопорядку (статті 437, 438 ККУ) - лише 71 [9]. При цьому забезпечення правової оцінки та належної кваліфікації воєнних злочинів та злочинів проти людяності, грубих порушень прав людини $\epsilon$ одним із важливих завдань у розбудові заходів із запобігання безкарності.
Ефективне розслідування й притягнення до відповідальності осіб, причетних до найтяжчих злочинів, учинених у рамках збройного конфлікту в Україні, потребує законодавчого врегулювання процесуальних питань щодо спеціального кримінального провадження (за відсутності особи in absentia) по такій категорії справ. Для прикладу, неврегульованою залишається проблема виконання вимог ст. 135 КПК України щодо порядку здійснення виклику та повідомлення у кримінальному провадженні осіб, які перебувають на тимчасово окупованій території. Аналіз судової практики щодо проваджень по АР Крим та м. Севастополь свідчить про те, що суди відмовляють у задоволенні клопотання про проведення спеціального досудового розслідування, зокрема через порушення порядку вручення процесуальних документів підозрюваному під час здійснення спеціального досудового розслідування згідно зі ст. 297-5 КПК України. А саме, враховуючи, що більшість підозрюваних переховується від слідства за межами підконтрольних Україні територій, суди встановлюють неналежність повідомлення особи про виклик та підозру, мотивуючи рішення у тому числі тим, що засоби масової інформації загальнодержавного розповсюдження недоступні на окупованій території, а направити повідомлення чи процесуальній документи на цю територію неможливо через відсутність поштового сполучення внаслідок окупації (наприклад, поштовий зв'язок АТ «Укрпошта» в АР Крим та м. Севастополь не здійснюється з 27.03.2014) та існуючу політику невизнання спроби анексії. Фактично для початку процесу переслідування підозрюваного в рамках такого провадження необхідно забезпечити його оголошення в міжнародний або міждержавний розшук. Виходячи з практики українських правоохоронних органів, Інтерпол через наявність політичного складника (особливо в провадженнях щодо державної зради тощо) здебільшого відмовляється оголошувати в міжнародний розшук підозрюваних у правопорушеннях на тимчасово окупованих територіях.

При цьому, наприклад, практика європейських країн $\epsilon$ досить обережною у застосуванні процедури in absentia. У країнах із системою прецедентного права така процедура взагалі не застосовується через надто великі ризики порушення права обвинуваченого на справедливий суд. Так, під час розслідування справ, пов'язаних зі збройним конфліктом, на одній чаші важелів опиняється потреба у забезпеченні своєчасного правосуддя, тоді як на другій - права обвинуваченого на справедливий розгляд. 
Також потребує вирішення й питання визначення механізму розслідування злочинів проти людяності, воєнних злочинів, а також їх подальшого судового розгляду. За останні десятиріччя як наслідок страшних злочинів Другої світової війни, чисельних збройних конфліктів по всьому світу та впливу системи ООН на їх врегулювання можна відзначати значний розвиток міжнародного кримінального правосуддя, що у підсумку призвів до прийняття країнами Римського статуту та утворення Міжнародного кримінального суду. Однак виходячи з міжнародного досвіду та, як уже зазначалося вище, великий обсяг завдань щодо розслідування та притягнення до кримінальної відповідальності за найтяжчі злочини буде покладатися саме на національну правову систему та механізми. При цьому для того, щоб визначитися з підходами до створення механізму державі, варто вивчити досвід інших країн, відповісти на питання щодо мети такого механізму в Україні (до прикладу, чи буде він сприяти примиренню, прагнути встановити правду про події війни тощо), визначитися щодо необхідності залучення до його роботи іноземних фахівців та ін. У світі існують чисельні приклади моделей та механізмів правосуддя по найтяжчих злочинах, проте Україна досі фактично не визначалися зі своїм. При цьому окремі представники системи правосуддя самі зазначають про недостатню спроможність та рівень підготовки правників із міжнародного гуманітарного права та міжнародного кримінального права задля розгляду справ, пов'язаних зі збройним конфліктом [9].

Водночас важливо відзначити й поступовий розвиток системи національних правоохоронних органів та правосуддя щодо розслідування цієі категорії злочинів, що саме по собі свідчить про фактичне створення окремих елементів такого механізму. Так, у 2018 р. було затверджено стратегію розвитку прокуратури Автономної Республіки Крим в умовах тимчасової окупації на 2019-2021 роки, що покликана окреслити підходи до роботи прокуратури автономії в умовах спроби анексії та збройного конфлікту з боку Російської Федерації з урахуванням норм міжнародного гуманітарного права. Нині у фокусі роботи відновлених та створених після тимчасової окупації правоохоронних органів АРК та м. Севастополь передусім перебувають саме питання розслідування воєнних злочинів, злочинів проти людяності та грубих порушень прав людини, вчинених на окупованому півострові. Наприкінці 2019 р. у структурі Офісу Генерального прокурора було створено Департамент нагляду у кримінальних провадженнях щодо злочинів, учинених в умовах збройного конфлікту, в роботі якого сотні кримінальних проваджень, зокрема щодо подій Іловайської трагедії, збиття літаку рейсу MH17, фактів розв'язання та ведення збройної агресії Росії, катувань та вбивств полонених військових і цивільних громадян, знищення та привласнення майна на окупованих територіях та ін. Відповідні управління задля розслідування найтяжчих злочинів під час збройного конфлікту за останній рік були створені й у прокуратурах Луганської та Донецької областей.

Розвиток спроможності національної правоохоронної системи задля забезпечення документування та розслідування найтяжчих злочинів, очевидно, межує з питаннями та викликами у сфері можливого застосування амністії чи люстраційних заходів. Так, наприклад, більшість населення, яке залишається проживати на тимчасово окупованих територіях, досі очікує від влади України відповідей на питання щодо визначення категорій осіб та мір відповідальності (або уникнення відповідальності) за співпрацю з окупаційною владою. А саме йдеться про тих громадян України, які не вчиняли найтяжчих злочинів, але їхні нерідко вимушені дії щодо співпраці з окупаційними адміністраціями в різній формі можуть бути кваліфіковані як державна зрада або посягання на територіальну цілісність і недоторканість України, або іншим чином. Указана ситуація не лише вимагає від правоохоронних органів розслідування десятків тисяч фактів імовірних злочинів, учинених особами на тимчасово окупованих територіях, а й створює перешкоди для розбудови подальшої політики реінтеграції та підживлює страхи наших громадян із цих територій.

Підходи перехідного правосуддя визначають обов'язковість забезпечення документування, розслідування та притягнення до відповідальності осіб, які вчинили воєнні злочини, злочини проти людяності та грубі порушення прав людини. Тоді як держава може встановити, що більшість цивільного населення на тимчасово окупованих територіях не понесе кримінальної відповідальності виключно у зв'язку з місцем свого проживання чи із зайняттям певних посад, звичайно, якщо їхні дії не містили складу воєнних злочинів, злочинів проти людяності, грубих порушень прав людини. Так, саме такої позиції схильні дотримуватися більшість з опитаних у рамках дослідження Київського міжнародного інституту соціології у травні-червні 2020 р. серед репрезентативної вибірки для дорослого населення віком 18 років і старше [8, див. результати відповідей на питання 2 дослідження]. 
Висновки. Запровадження системного та ефективного документування та розслідування найтяжчих злочинів в умовах збройного конфлікту в Україні - безумовно, важливий елемент перехідного правосуддя, впровадження якого $\epsilon$ необхідним для комплексного подолання наслідків триваючого збройного конфлікту з Російською Федерацією. Формування ефективних національних систем правосуддя у цьому напрямі має базуватися на законодавстві, що відповідає міжнародним стандартам у галузі прав людини та поточним потребам і реаліям конкретної країни. Розбудова роботи українських правоохоронних органів щодо документування та розслідування злочинів унаслідок збройного конфлікту може свідчити про наявність бажання проводити ефективні розслідування за такою категорією злочинів. При цьому відсутність доступу на тимчасово окуповані території та існуючі прогалини в законодавстві свідчать про неможливість відповісти на виклики, пов'язані з необхідністю забезпечувати заходи із запобігання безкарності. Тож влада, застосовуючи діалогові інструменти, має сформувати та послідовно впроваджувати стратегію розвитку потенціалу національних органів розслідування та правосуддя щодо найтяжчих злочинів у рамках збройного конфлікту з урахуванням потреб потерпілих та дотриманням стандартів справедливого судочинства.

\section{Література}

1. Закон України «Про забезпечення прав i свобод громадян та правовий режим на тимчасово окупованій території України» № 1207-VII від 15.04.2014. URL: https://zakon.rada.gov.ua/laws/ show/1207-18\#Text.

2. Марчук І., Ванігасурія А. МКС завершив попереднє вивчення ситуації щодо Криму і Донбасу: яка подальша доля ситуації України? URL: https: / / www.ejiltalk.org/the-icc-concludes-itspreliminary-examination-in-crimea-and-donbas-whatsnext-for-the-situation-in-ukraine/.

3. Отчет о действиях по предварительному расследованию ОП МКС, 2016 г. (п. 158).
URL: https://www.icc-cpi.int/iccdocs/otp/161114otp-rep-pe-ukraine.pdf.

4. Заява прокурора Фату Бенсуди щодо завершення попередньої експертизи ситуації в Україні. 11 грудня 2020 р. URL: https: / cutt.ly/ukV9DGU.

5. Доповідь Генерального секретаря $\mathrm{OOH}$ «Господство права та правосуддя перехідного періоду в конфліктних та постконфліктних суспільствах». URL: https://documents-dds-ny.un.org/doc/UNDOC/ GEN/N04/395/31/PDF/N0439531.pdf.

6. Щорічна доповідь Верховного комісара 3 прав людини Організації Об'єднаних Націй і Генерального секретаря «Аналітичне дослідження 3 питань прав людини і правосуддя перехідного періоду». 06.08.2009. URL: https://undocs.org/ru/A/ $\mathrm{HRC} / 12 / 18$.

7. Резолюція Ради з прав людини ООН 12/11 «Права людини і правосуддя перехідного періоду» (пункт 3 порядку денного 12 сесії). 12.10.2009. URL: https://documents-dds-ny.un.org/doc/RESOLUTION/ GEN/G09/165/94/PDF/G0916594.pdf.

8. Результати опитування Київського міжнародного інституту соціології за підтримки Програми розвитку ООН (ПРООН). Серпень 2020 р. URL: https://cutt.ly/7kV9GD6.

9. Звіт «Право на правду. Висвітлення судових процесів, пов'язаних зі збройним конфліктом в Україні» / Медійна ініціатива за права людини. URL: http://mipl.org.ua/wp-content/uploads/2020/05/ Zvit_MIPL_25-05-20.pdf.

Конопельський В. Я., доктор юридичних наук, професор, завідувач кафедри кримінального права та кримінології

Одеського державного університету внутрішніх справ

Свиридова Д. О., аспірант кафедри кримінального права та кримінології

одеського державного університету внутрішніх справ 